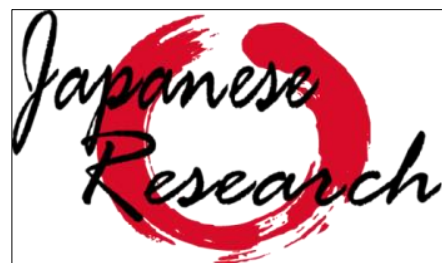

on Linguistics, Literature and Culture
Japanese Research on Linguistics, Literature, and Culture

Vol. 2 No. 2 May 2020, Hal. 143-160 ISSN online: 2655-4836

Doi: 10.33633/jr.v2i2.3978

http://publikasi.dinus.ac.id/index.php/jrllc/article/view/3978/2027

japanese.research@fib.dinus.ac.id

Published by Universitas Dian Nuswantoro, Semarang

\title{
Pemaknaan Lirik Lagu Shabondama Karya Ujo Noguchi Berdasarkan Analisis Semiotika Michael Riffaterre
}

\author{
Fajria Noviana, Akhmad Saifudin \\ Universitas Diponegoro \\ Universitas Dian Nuswantoro \\ fajrianoviana@lecturer.undip.ac.id
}

Article History: Submitted date 2020-08-20; Accepted date 2020-09-1; Published date 2020-09-2

\begin{abstract}
Shabondama is a children's song whose lyrics are composed by Ujo Noguchi. This song tells about a game of soap balloons. Interestingly, even though it tells about children's play, this song seems mysterious. There are nuances of sadness when listening to this song. The diction used has a negative connotation, unlike most other children's songs which are cheerful and use words that have a positive connotation. This is what motivates the writer's interest in examining more deeply what the real meaning is contained in the song. The semiotic theory of Riffaterre's poetry was used to study it. Through the process of heuristic reading, hermeneutic reading, and intertext studies, the result shows that the meaning contained in this song is helplessness or weakness.
\end{abstract}

Keywords: semiotics, poetry, Riffaterre, semantic indirection

\begin{abstract}
Abstrak
Shabondama adalah lagu anak yang liriknya dikarang oleh Ujo Noguchi. Lagu ini menceritakan permainan balon sabun. Menariknya, meskipun bercerita tentang permainan anak namun lagu ini terkesan misterius. Ada nuansa kesedihan ketika mendengarkan lagu ini. Diksi yang digunakan pun berkonotasi negatif, tidak seperti kebanyakan lagu anak lainnya yang ceria dan menggunakan kata-kata yang berkonotasi positif. Inilah yang melatarbelakangi ketertarikan penulis untuk mengkaji lebih dalam apa makna sebenarnya yang terkandung di dalam lagu itu. Untuk mengkajinya digunakan teori semiotika puisi Riffaterre. Melalui proses pembacaan heuristik, hermeneutik, dan studi interteks, diperoleh hasil bahwa makna yang terkandung dalam lagu ini adalah ketidakberdayaan.
\end{abstract}

Kata Kunci: semiotika, puisi, Riffaterre, ketidaklangsungan semantik 


\section{Pendahuluan}

Ketika mendengar lagu anak Jepang berjudul Shabondama 'gelembung sabun' sepintas kita akan dapat dengan mudah memahami maksud atau isi pesan dari lagu tersebut. Bahasa yang digunakan sederhana dengan kata-kata yang mudah dipahami, sehingga wajar saja jika lagu tersebut dikenal sebagai lagu anak dan bahkan dikategorikan sebagai lagu pengantar tidur. Lagu Shabondama memang sangat dikenal di Jepang karena diajarkan di sekolah dasar dan melodi lagu ini digunakan sebagai pengantar keberangkatan kereta di stasiun Yumoto, Iwaki.

Lagu Shabondama berisi tentang permainan anak yang populer, yakni membuat dan menerbangkan gelembung sabun dengan cara ditiup menggunakan sedotan. Sedotan dicelupkan ke dalam air sabun kemudian ditiup pelan-pelan sampai menggelembung dan dilepaskan dari ujung sedotan agar bisa terbang melayang. Biasanya gelembung yang terbentuk tidak dapat bertahan lama, terbang melayang sebentar, kemudian meletus karena angin atau mengenai sesuatu benda, bahkan sebelum terbang pun seringkali sudah pecah waktu ditiup. Bentuk gelembung sabun yang tercipta sangat indah, transparan, dan memantulkan cahaya warna-warni layaknya pelangi. Sayangnya karena terbuat dari air sabun, shabondama tidak dapat bertahan lama karena rapuh.

Apabila kita membaca lirik lagu tersebut, sepintas tidak ada makna lain yang terkandung dalam kata-kata atau kalimat yang menyusun lagu tersebut. Bahasa yang digunakan sederhana, menggunakan kosa kata yang terbatas dan mudah dipahami, serta disusun dengan kalimat yang runtut, koheren, dan membentuk satu cerita utuh, yakni menceritakan permainan shabondama yang digemari anak-anak. Faktor-faktor inilah yang menjadikan lagu ini dimasukkan ke dalam genre doyo 'lagu anak' karena liriknya sederhana, mudah dipahami, dan mampu membuat anakanak berimajinasi dengan lagu tersebut.

Namun apabila kita berasumsi bahwa karya sastra, dalam hal ini berupa lagu atau lirik lagu, merupakan media bagi pengarang untuk menyampaikan pesannya secara tidak langsung, maka kita perlu menduga bahwa bahasa yang digunakan oleh pengarang dalam lirik lagu Shabondama mempunyai maksud atau makna yang lain. Sebelum dijadikan lagu, Shabondama merupakan sajak yang dikarang oleh Ujo Noguchi. Sajak itu kemudian dimusikalisasi dan diaransemen oleh Shinpei Nakayama dengan nada lagu yang merupakan modifikasi dari lagu 
berjudul Jesus Loves Me (Shuware wo Aisu) (http://eternal-life.la.coocan.jp/ preachings2008/08.09/09.17.htm). Sajak adalah bentuk karya sastra bagian dari puisi yang teratur dan terikat dalam baris-barisnya (KBBI). Kekuatan utama sajak adalah adanya keselarasan bunyi dan makna dalam kata-kata yang digunakan untuk menyusun sajak. Seperti halnya karya sastra yang lain, terutama karya sastra pendek seperti puisi, pantun, ataupun haiku, isinya merupakan reaksi dari pengarangnya terhadap pengalaman yang dialaminya. Karena bentuknya yang pendek, maka bahasa yang digunakan untuk menyusun sajak sarat dengan makna sehingga orang awam tidak akan dengan mudah memahami apa yang sebenarnya ingin disampaikan oleh pengarangnya. Oleh karena itu, dalam artikel ini penulis mencoba menginterpretasi makna atau pesan dari lagu Shabondama karya Ujo Noguchi berdasarkan teori semiotika yang diadaptasi dari teori Riffaterre (1978) tentang semiotika puisi.

Lagu Shabondama sendiri sudah cukup banyak dikaji, namun kajian-kajian tersebut umumnya mengaitkan lagu ini dengan beberapa lagu karya Ujo Noguchi lainnya, atau mengkaji lagu ini secara struktural. Salah satunya adalah tulisan berjudul Keterkaitan Makna dalam Tiga Lirik Lagu Anak Jepang Karya Noguchi Ujo Ditinjau melalui Pendekatan Ekspresif (2016). Tiga lagu yang dianalisis adalah Akai Kutsu, Nanatsu no Ko, dan Shabondama. Dalam tulisannya, Yorice dan Noviana mengungkapkan bahwa ketiga lagu tersebut merupakan curahan perasaan yang muncul dari kehidupan Noguchi, tepatnya tentang sosok yang sangat berarti dan berharga bagi penyair. Curahan rasa sedih, sesal, rindu, dan kasih sayang Noguchi kepada mereka tergambar jelas dalam ketiga lagu tersebut.

\section{Kajian Teoretis}

\subsection{Latar Belakang Kehidupan Pengarang}

Noguchi (29 Mei 1882 - 27 Januari 1945) merupakan salah satu sastrawan yang dikenal banyak menulis cerita rakyat dan lagu anak-anak. Bersama Hakushu Kitahara dan Yaso Saijo, ia dikatakan telah meletakkan dasar-dasar lagu anak-anak Jepang modern (https://www.kodomo.go.jp/gallery/KODOMO WEB/authors/noguchi e.html). la menghasilkan banyak lirik yang kemudian diaransemen menjadi lagu anak-anak, di antaranya adalah Nanatsu no Ko 'Tujuh Anak Gagak', Aoi Me no Ningyo 'Boneka Bermata Biru', Akai Kutsu 'Sepatu Merah', 
dan tentu saja Shabondama. Noguchi hidup pada tiga zaman, yakni zaman Meiji (1867-1912), Taisho (1912-1926), dan Showa (1926-1989). Zaman kehidupan Noguchi dikenal sebagai masa peralihan, yaitu peralihan menuju modernisasi Jepang yang diawali pada masa Meiji atau yang dikenal sebagai Restorasi Meiji.

Pada masa-masa itu sebenarnya perkembangan sastra di Jepang cukup dinamis. Cukup banyak sastrawan yang dikenal pada masa-masa tersebut, di antaranya adalah Toson Shimazaki, Soseki Natsume, Ogai Mori, dan Ryunosuke Akutagawa. Namun sayangnya, oleh pemerintah Jepang, sastra bukan dianggap sebagai prioritas pembangunan karena tidak langsung berpengaruh signifikan terhadap modernisasi Jepang dibandingkan dengan masalah teknologi dan industri. Kegiatan sastra yang memperoleh perhatian dari pemerintah hanya seputar penerjemahan buku-buku dari Barat dan karya sastra yang isinya mendukung propaganda bagi modernisasi Jepang.

Modernisasi Jepang pada saat itu memang berhasil mengangkat nama Jepang hingga dikenal sebagai salah satu negara maju di Asia dan bahkan dunia. Kekuatan militer dan ekonomi Jepang meningkat dengan pesat. Namun sebenarnya di dalam negeri terjadi ketimpangan sosial dan ekonomi. Jepang yang lebih memprioritaskan kemajuan militer dan industri telah mengorbankan para petani di pedesaan yang sebelumnya menjadi penyokong utama kehidupan di Jepang. Kebijakan pemerintah Jepang yang menaikkan pajak untuk pertanian sangat menyengsarakan kehidupan petani di pedesaan. Akhirnya banyak pemuda desa yang meninggalkan desanya untuk bekerja sebagai buruh industri di kota (Beasley, 2003).

Kesengsaraan petani desa pada waktu itu mengakibatkan banyak korban, terutama anakanak. Jepang pada saat itu bukanlah negara yang maju dalam hal pertanian seperti saat ini. Para petani hanya dapat menanam padi pada saat musim semi dan ditambah lagi dengan kebijakan pemerintah yang menaikkan pajak menambah beban mereka semakin berat. Hanya untuk makan sendiri saja sudah susah apalagi memberi makan keluarga. Sebagai akibatnya banyak anak-anak meninggal, baik karena penyakit (terutama TBC), kekurangan gizi, maupun akibat "dibunuh" oleh orang tuanya karena tidak mampu memberi makan. Tindakan pembunuhan ini dikenal sebagai mabiku 'menjarangkan', yakni orang tua membunuh anaknya yang baru lahir dengan cara menutup hidung bayi dengan kain basah (https://peoplepill.com/people/ujo-noguchi/). 
Dari sisi kehidupan politik, sebenarnya Jepang saat itu tidak benar-benar melaksanakan demokrasi. Demokrasi yang menjadi bagian dari modernisasi dalam bidang politik hanya menjadi slogan propaganda pemerintah dan dijalankan pada hal-hal yang menguntungkan pemerintah. Realitas yang terjadi banyak terjadi pemaksaan dan pembatasan kegiatan atau pemikiran yang dianggap berpotensi mengganggu negara. Dengan mengatasnamakan Kaisar dan negara pemerintah Jepang tidak segan-segan menghukum orang atau pihak yang dianggap mengganggu jalannya pemerintahan. Dengan menggunakan slogan fukoku kyohei 'negara kaya militer kuat' pemerintah Jepang melalui program wajib militer dapat memobilisasi rakyatnya untuk dimanfaatkan sebesar-besarnya demi kepentingan negara. Demokrasi yang dijalankan setengahsetengah dengan prinsip wakon yosai 'Kepribadian Jepang Pemikiran Barat' juga berdampak pada krisis identitas orang Jepang (Aminah, 2015). Derasnya hal-hal yang berbau Barat masuk ke Jepang mau tidak mau telah mengikis kepribadian tradisional orang Jepang.

Pada masa seperti inilah Noguchi hidup dan menciptakan karya-karyanya. Dalam riwayat kehidupannya, Nobuchi pada tahun 1908 pernah mempunyai anak perempuan yang bernama Midori dari istrinya yang bernama Hiro Takashio. Anak tersebut meninggal dunia hanya dalam usia tujuh hari. Dikatakan dalam literatur bahwa kematian anaknya yang baru berusia tujuh hari inilah yang melatarbelakangi penciptaan sajak Shabondama. Ketika itu Noguchi melihat sekelompok anak yang sedang bermain Shabondama dan ia teringat akan anaknya yang tidak mempunyai kesempatan hidup lama. Peristiwa inilah yang melatarbelakangi terciptanya sajak Shabondama (https://peoplepill.com/people/ujo-noguchi/).

\subsection{Semiotika dalam Puisi}

Karya sastra pada dasarnya adalah produk dan menjadi bagian dari kajian bahasa karena diciptakan dan dinikmati dengan menggunakan bahasa. Bahasa merupakan sistem tanda bunyi yang divisualkan melalui tulisan. Sebagai sebuah tanda tentunya juga mempunyai sifat arbriter

karena dalam pemaknaannya sangat tergantung pada pengalaman, konsensus, ataupun konteksnya. Keberadaan tanda digunakan untuk menyederhanakan konsep yang ada dalam pikiran manusia yang bersifat abstrak dan kompleks. 
Ilmu yang mempelajari pemaknaan tanda disebut semiotika. Semiotika mempelajari tanda secara umum yang dapat berupa tanda bunyi, gambar, gerak, dan lainnya. Tanda itu sendiri mempunyai konsep "sesuatu yang mewakili sesuatu yang lain". Sebagai contoh adalah sesuatu yang berupa gambar sendok garpu yang biasa kita temui di jalan sebagai salah satu rambu lalu lintas, mewakili atau berarti sebuah informasi yang menjelaskan bahwa tempat itu adalah restoran, atau dengan kata lain tanda sendok garpu sama dengan restoran.

Dalam pandangan penulis pemaknaan karya sastra, terutama puisi, sajak, ataupun lirik lagu akan sangat tepat jika menggunakan ancangan semiotik. Bahasa sendiri sudah merupakan tanda, lebih lagi bahasa yang digunakan dalam puisi. Bahasa yang digunakan dalam puisi berbeda dengan bahasa sehari-hari. Bahasa puisi, entah dikarenakan masalah keindahan, efisiensi, ataupun nuansa yang sesuai, acapkali tidak sesuai struktur yang baku (tidak gramatikal) dan menggunakan diksi yang tidak familiar. Keduanya seringkali justru menjadi kunci dalam memahami pesan puisi. Kita sebagai pembaca dituntut untuk lebih peka dan jeli dalam memahami bagian-bagian tersebut.

\subsection{Semiotika Puisi Riffaterre}

Riffaterre, dalam bukunya yang berjudul Semiotics of poetry, menyatakan bahwa puisi atau sajak itu menyampaikan sesuatu dengan bahasa tertentu tetapi dengan maksud yang lain (1971: 1). 'Sesuatu' yang dimaksudkan di sini artinya tidak terdapat dalam kata-kata yang digunakan dalam puisi. Oleh Riffaterre, 'sesuatu' itu disebutnya matriks, yakni makna atau pesan dari sebuah puisi, yang sebenarnya menjadi dasar dari penciptaan puisi. Pengarang mengungkapkan maksudnya dalam bentuk puisi, sehingga dapat dikatakan bahwa puisi adalah penjabaran yang lebih panjang dan kompleks dari sebuah matriks.

Memahami puisi bukanlah perkara yang sederhana. Dalam kaitannya dengan hal ini, Riffaterre menyatakan beberapa faktor penting yang menjadi sifat puisi sekaligus berguna dalam memahami puisi, yakni ketidaklangsungan ekspresi dan tahapan pemaknaan puisi. 


\section{Ketidaklangsungan semantik}

Dalam puisi seringkali terjadi neologisme, yakni penciptaan makna baru oleh pengarang yang muncul berdasarkan pandangan atas pengalaman yang dirasakannya. Neologisme dalam puisi berbeda dengan penggunaan bahasa sehari-hari (Riffaterre, 1983), karena bahasa puisi tidak terikat pada tata bahasa yang baku dan lebih mengedepankan faktor seni atau keindahan. Bahasa yang digunakan dalam puisi berbeda dengan maksud sebenarnya, terjadi ketidaklangsungan ekspresi secara semantik. Riffaterre menunjukkan bahwa terdapat tiga hal yang berpengaruh pada penggunaan bahasa puisi yang mengakibatkan ketidaklangsungan semantik dalam puisi. Ketiga hal tersebut adalah penggantian arti, penyimpangan arti, dan penciptaan makna baru (1978: 2). Hal yang pertama terjadi tatkala suatu kata yang sebenarnya mewakili makna tertentu yang sudah disepakati bersama dalam masyarakat digunakan untuk mewakili kata yang lain karena adanya kemiripan atau dianggap dapat mewakili kata yang lain. Dengan kata lain terjadi figurasisasi berupa metafora atau metonimi. Sebagai contoh adalah penyimpangan makna bunga yang dimaknai sebagai gadis cantik karena adanya analogi dalam bentuknya yang indah. Hal yang kedua, yakni penyimpangan arti, terjadi karena ambiguitas, kontradiksi ataupun nonsense. Ambiguitas dapat terjadi pada kata, frasa, kalimat, dan bahkan wacana yang multitafsir, dan kontradiksi disebabkan adanya penggunaan bahasa yang bermakna ironi, paradoks atau antitesis, serta nonsense yang berarti adanya penggunaan kata-kata yang secara linguistik sebenarnya tidak mempunyai arti (tidak terdapat di kamus) namun kehadirannya dapat memberi makna atau kesan "gaib". Terakhir, yakni penciptaan makna baru terjadi karena pemaknaan yang berasal dari pengorganisasian ruang teks dari sesuatu yang merupakan unsur linguistik, seperti rima, simetri, atau ekuivalensi semantik antara homolog dalam bait-bait puisi.

\section{Tahapan dalam memaknai puisi}

\section{1) Pembacaan heuristik dan hermeneutik}

Karya sastra pada dasarnya adalah dialektika antara teks dan pembacanya. Untuk dapat memahami teks, pembaca harus menguasai konvensi bahasa. la harus menguasai tataran 
fonologi, morfologi, dan sintaksis, serta semantik. Meskipun dunia pemaknaan dikatakan sebagai wilayahnya pembaca, namun tidak berarti pembaca dengan semena-mena memaknai pesan sebuah puisi. la harus secara logis dapat menghubungkan antara teks dan maknanya. Ada dua proses pembacaan yang disebutkan oleh Riffaterre, yakni pembacaan heuristik dan hermeneutik.

Proses pembacaan pertama, yakni heuristik, adalah pembacaan keseluruhan teks puisi berdasarkan unsur-unsur linguistik pembentuknya, berdasarkan tata bahasa normatifnya, atau didasarkan pada konvensi bahasanya yang meliputi unsur linguistik fonologi, morfologi, sintaksis, dan semantik. Proses ini menghasilkan makna teks yang disebut oleh Riffaterre (1978) sebagai sistem semiotika tingkat pertama 'first order semiotics system' atau meminjam istilah Grice dalam ilmu pragmatik sebagai makna eksplikatur atau makna tuturan bukan makna yang 'dimaksudkan' oleh penuturnya.

Proses pembacaan berikutnya adalah pembacaan hermeneutik. Ini adalah proses decoding, yakni pembaca menafsirkan 'kejanggalan/ketidakgramatikalan' ataupun makna 'dibalik' teks yang ada dalam puisi. Oleh Riffaterre proses ini disebut pembacaan retroaktif (berulang-ulang) sebagai sistem semiotik kedua. Dalam proses ini pembaca berusaha menemukan makna 'yang dimaksudkan' yang biasanya terjadi sebagai dampak penggunaan ekspresi bahasa tidak langsung yang ditemukan pada proses pembacaan heuristik. Hasil pembacaan hermeneutik adalah pembaca dapat menemukan kesatuan makna puisi yang dibacanya.

2) Matriks, model, dan varian

Matriks adalah inti atau kata kunci yang menjadi makna utama dalam puisi. Menurut Riffaterre penciptaan teks puisi berawal dari sebuah matriks (1978: 12). Matriks berupa satuan bahasa minimal dan bermakna harfiah, yakni dapat berupa kata, frasa, klausa, ataupun kalimat sederhana yang kemudian ditransformasikan ke dalam parafrasa yang lebih panjang, kompleks, dan tidak harfiah (1978: 19). Tranformasi matriks diwujudkan dalam suatu model yang dijabarkan dalam varian-varian sehingga membentuk keseluruhan teks puisi. Matriks tidak muncul dalam teks puisi, tetapi justru menjadi penopang utama dalam puisi. Kehadiran matriks layaknya lubang kosong dalam kue donat, tanpa adanya lubang kosong kue tersebut tidak dapat disebut donat. 
Kehadiran matriks dapat diinterpretasikan melalui aktualisasinya berupa model, sebagai aktualisasi pertama, dan penjabarannya dalam bentuk varian-varian sebagai aktualisasi berikutnya. Model dapat ditemukan pada unsur puisi (kata, frasa, kalimat) yang sekiranya merepresentasikan matriks, biasanya berupa bahasa puitis yang menjadi pokok pembicaraan. Sementara varian adalah penjabaran-penjabaran yang biasanya menjelaskan modelnya.

\section{3) Intertekstualitas}

Karya sastra tidak hadir secara serta merta. la hadir sebagai respon atas karya sastra yang lain. Inilah yang disebut intertekstualitas: bahwa sebuah karya sastra berhubungan dengan karya sastra yang lain, atau berhubungan dengan teks yang lain. Interpretasi komprehensif terhadap karya sastra hanya mungkin dilakukan oleh pembaca melalui interteks, yaitu dengan mengacu kepada teks-teks lain (Riffaterre, 1978:149), baik teks secara harafiah maupun teks dalam pengertian universal. Riffaterre menyebutnya dengan istilah hipogram. Sebuah istilah yang terinspirasi dari Saussure tentang paragram, yaitu sesuatu yang tersembunyi di balik kata-kata. Hipogram merupakan ide dasar yang melatari penciptaan sebuah karya sastra.

Keberadaan hipogram merupakan respon terhadap teks lain. Teks yang dimaksudkan di sini dapat berupa karya sastra yang lain, maupun teks universal seperti latar belakang pengarang, kondisi sosial budaya saat karya sastra lahir, dan sebagainya. Teeuw (1984) menyatakan bahwa latar penciptaan karya sastra dapat meliputi masyarakat, peristiwa sejarah, kejadian alam, dan kehidupan. Hipogram pada dasarnya adalah matriks, yaitu sesuatu yang menjadi pusat makna yang mengisi ruang kosong dalam sebuah puisi. Riffaterre membagi hipogram dalam dua jenis, yaitu hipogram potensial dan aktual. Hipogram potensial adalah hipogram yang aktualisasinya nampak dalam model dan varian-variannya dalam teks puisi. Sementara hipogram aktual adalah hipogram yang berupa teks-teks lain yang telah ada sebelumnya.

\section{Metode Penelitian}

Penelitian ini menggunakan paradigma kualitatif dengan ancangan semiotik. Sumber data berupa sajak Shabondama karya Ujo Nobuchi. Data yang berupa teks sajak Shabondama dianalisis berdasarkan teori semiotika puisi Michael Riffaterre (1978). 


\section{Hasil dan Pembahasan}

Sajak Shabondama terdiri atas tiga bait, dua bait pertama terdiri atas 3 baris dan bait terakhir dua baris. Berikut adalah sajak Shabondama.

Shabondama

'Gelembung Sabun'

Shabondama tonda.

terbang (PST)

Yane made tonda.

atap sampai terbang (PST)

Yane made tonde, kowarete kieta.

atap sampai terbang (CONJ), rusak (CONJ) hilang (PST)

Shabondama kieta.

hilang (PST)

Tobazuni kieta.

terbang (NEG) hilang (PST)

Umarete sugu ni, kowarete kieta.

lahir(CONJ)segera, rusak(CONJ) hilang (PST)

Kaze kaze fuku na!

Angin angin bertiup (NEG IMP)

Shabodama tobaso.

terbang(VOC)

Keterangan:

PST : Past tense

CONJ : Conjunction

NEG : Negative

IMP : Imperative

VOC : Vocative
(1) 'Shabondama terbang.'

(2) 'sampai atap terbang.'

(3) 'sampai atap terbang, lalu pecah dan hilang.'

(4) 'Shabondama musnah.'

(5) 'Belum terbang sudah musnah.

(6) 'Baru muncul sudah hancur dan musnah.'

(7) 'Angin angin, jangan bertiup!'

(8) 'Shabondama terbanglah.'

\subsection{Pembacaan heuristik}

Judul sajak adalah Shabondama ‘Gelembung Sabun’ yang seperti sudah dipaparkan dalam bagian pendahuluan merupakan permainan anak berbahan air dicampur sabun yang digelembungkan dengan cara ditiup sedotan. Berdasarkan hasil pembacaan heuristik isi sajak menceritakan bagaimana balon sabun yang ditiup tidak dapat bertahan lama dan bahkan ada yang sudah pecah ketika baru ditiup. Dari hasil analisis linguistik, baik morfologi, sintaksis, maupun semantik tidak ditemukan kejanggalan atau sesuatu yang ungramatical. Diksi yang digunakan juga sangat terbatas, beberapa kata diulang-ulang, serta mudah dipahami. Secara 
morfologi kata-kata yang digunakan semuanya wajar dan tidak ditemukan kata-kata yang keliru penggunaannya. Susunan kata-kata pada setiap baris dan bait sajak juga memenuhi aturan sintaksis bahasa Jepang. Pun dengan maknanya, baik kohesi, koherensi, maupun diksi yang digunakan tidak ada yang tidak wajar. Penggunaan kata, susunan kalimat, serta makna dalam sajak tersebut mampu membentuk informasi cerita yang mudah dipahami. Singkatnya, dalam proses pembacaan heuristik tidak ditemukan ketidakgramatikalan dan isi sajak adalah menceritakan permainan Shabondama.

\subsection{Pembacaan hermeneutik}

Meskipun tidak ditemukan kejanggalan dalam proses pembacaan heuristik, dengan asumsi bahwa karya sastra adalah ekspresi bahasa untuk mengungkapkan suatu pesan dengan'cara lain, dilanjutkan dengan pembacaan hermeneutik. Biasanya, dalam pembacaan ini dilakukan dengan cara menafsirkan kejanggalan atau ketidakgramatikan yang ditemukan dalam pembacaan heuristik. Namun karena dalam sajak ini tidak ditemukan kejanggalan, maka yang dilakukan adalah menghubungkannya dengan dunia di luar linguistik. Pertama adalah dengan mengamati kesesuaian tema lagu dengan genrenya. Telah disebutkan di bagian pendahuluan bahwa lagu Shabondama dikategorikan sebagai lagu anak dan lagu pengantar tidur untuk anakanak. Dari hasil pengamatan ditemukan kejanggalan dalam penggunaan diksi yang dipakai dan aransemen lagu. Diksi yang dipakai dalam lagu tersebut bukan diksi yang umum dipakai untuk lagu anak-anak. Kata-kata yang dominan digunakan, yaitu kowareru 'rusak', kieru 'musnah' berkonotasi negatif. Padahal biasanya diksi yang digunakan untuk lagu anak berkonotasi positif untuk memotivasi anak pada hal-hal yang baik. Dalam hal aransemen lagu, ketika mendengar lagu Shabondama iramanya terdengar misterius, seperti ada jeritan dan kepiluan di balik irama lagu Shabondama.

Berbekal dengan dua kejanggalan tersebut, aktivitas berikutnya adalah mengaitkannya

dengan latar belakang kehidupan pengarang serta latar belakang sosial budaya saat lirik lagu Shabondama dikarang. Aktivitas ini pada dasarnya sama dengan kajian intertekstualitas. Melalui teks latar kehidupan pengarang, diketahui bahwa Noguchi sebagai pengarangnya, pernah mempunyai anak perempuan bernama Midori, yang meninggal dunia pada usia sekitar satu 
minggu. Meskipun tidak diketahui penyebabnya, saat itu di Jepang memang tingkat kematian bayi dan anak-anak tinggi yang disebabkan kelaparan dan wabah penyakit TBC.

Apabila dikaitkan dengan sejarah kehidupan pengarang, utamanya jika dikaitkan dengan kematian anaknya, maka ada kemungkinan shabondama yang dimaksudkan oleh pengarang adalah anak-anak. Apalagi inspirasi penciptaan lirik lagu ini juga pada saat melihat anak-anak sedang bermain shabondama dan ia teringat akan nasib anaknya. Di sini terjadi ketidaklangsungan ekspresi penggantian arti dengan memetaforakan anak-anak dengan shabondama. Metafora adalah gaya bahasa yang mengalihkan citra sesuatu kepada sesuatu yang lain (Saifudin, 2012) atau dalam studi kognitif dipahami sebagai konseptualisasi satu domain ke dalam domain yang lain (Saifudin, 2018). Dasar metafora adalah analogi, yaitu kemiripan unsur pada domain tertentu yang kemudian digunakan untuk domain yang lain. Analogi pada shabondama sebagai metafora dari anak-anak adalah bentuknya yang transparan, menarik, dan sifatnya yang rentan, mudah rusak dan pecah. Bentuk transparan mempunyai titik kemiripan dengan sifat anak-anak yang masih polos dan lugu, sementara kerentanan shabondama juga beranalogi dengan sifat anak-anak yang masih belum mapan dalam segi fisik maupun kejiwaannya.

Pemaknaan judul lagu Shabondama sebagai sebuah metafora secara logis berdampak pada pemaknaan isi keseluruhan lagu. Dalam arti bahwa diksi yang digunakan dalam isi lagu logikanya bukan makna harfiah, karena kata-kata yang digunakan dalam lirik lagu merupakan penjelasan dari shabondama. Untuk lebih jelasnya kita analisis baris per baris:

(1). Shabondama tonda. 'Shabondama terbang.'

Jika shabondama merupakan metafora dari anak-anak, maka tonda (bentuk lampau dari tobu yang berarti terbang) juga merupakan metafora. Terbang adalah aktivitas pergerakan yang titik awalnya dari bawah atau tepatnya dari tanah atau bumi bergerak menjauh ke atas. Idealnya karena massa jenisnya yang ringan, dengan dibantu hembusan shabondama akan dapat terbang jauh dan tinggi. Ini beranalogi dengan anak-anak yang seharusnya setelah dilahirkan dapat hidup dan tumbuh berkembang menjadi remaja, dewasa, sampai tua. Titik awal kehidupan adalah ketika dilahirkan bergerak menjauh dari kelahiran ditandai dengan perkembangan fisik yang bertambah besar dan tinggi. 
(2). Yane made tonda. 'Sampai atap terbang.'

Yane secara harfiah berarti atap, yaitu bagian atas rumah yang berfungsi melindungi rumah dari panasnya matahari dan air hujan. Kata yane kemudian diikuti dengan made yang berarti sampai menunjukkan bahwa yane adalah sebuah tujuan atau paling titik poin yang harus dilalui dalam rangka mencapai tujuan karena kata made tanpa dikuti partikel ni 'ke' tidak menunjukkan tujuan akhir. Ini mempunyai kemiripan dengan fase-fase pembagian usia manusia seperti usia bayi, balita, remaja, dewasa, dan tua.

(3). Yane made tonde, kowarete kieta. 'Sampai atap terbang, lalu pecah dan hilang.'

Makna harfiah dari kalimat baris (3) adalah Shabondama terbang hingga atap, kemudian pecah dan lenyap. Verba atau predikat yang digunakan dalam kalimat ini adalah tonde, kowarete, dan kieta. Tonde merupakan bentuk -te (bentuk konjungsi untuk menunjukkan urutan kejadian atau aktifitas) dari tobu yang berarti terbang, dan kowarete (bentuk -te dari kowareru) bermakna rusak. Verba terakhir yang digunakan adalah kieta (bentuk lampau dari kieru yang berarti hilang) yang berarti hilang atau musnah.

Kowarete dan kieta adalah verba yang berkonotasi negatif karena bermakna rusak dan musnah, yang dalam kalimat ini menjelaskan keadaan shabondama setelah terbang sampai atap kemudian pecah dan musnah. Kezadaan ini disamakan dengan kondisi anak-anak di Jepang pada saat itu yang menderita dan akhirnya meninggal sebelum mencapai usia dewasa.

Simpulannya isi dari bait pertama adalah menjelaskan kondisi anak-anak di Jepang pada saat lirik lagu ini diciptakan. Anak-anak yang masih polos, suci, dan menarik hati orang tuanya sudah harus merasakan penderitaan dan akhirnya meninggal. Sebuah kondisi yang sama dengan metafora shabondama yang dituliskan pengarang dalam lagu ini.

(4). Shabondama kieta. 'Shabondama (telah) musnah.'

(5). Tobazuni kieta. '(Bahkan) sebelum (sempat) terbang (telah) musnah.'

(6). Umarete sugu ni, kowarete kieta. 'Baru muncul sudah hancur dan musnah.'

Pada bait kedua, yang juga terdiri dari tiga baris kalimat (4), (5), dan (6) menjelaskan kondisi yang lebih parah dibandingkan dengan kondisi pada bait pertama. Ini memberikan 
penegasan bahwa pada saat itu kondisi Jepang sudah sangat parah, banyak anak-anak yang baru dilahirkan, belum sempat mengenyam kehidupan langsung meninggal.

Isi bait pertama dan kedua pada dasarnya menyampaikan topik yang sama, yaitu tentang apa yang dialami anak-anak Jepang. Bait kedua memberikan tambahan penegasan tentang apa yang disampaikan oleh pengarang.

Kemudian pada bait ketiga di baris (7) pengarang menambahkan subjek yang lain, yaitu kaze 'angin', setelah pada bait pertama semua bersubjek shabondama.

(7). Kaze kaze fuku na. 'Angin angin jangan bertiup.'

(8). Shabondama tobaso. 'Shabondama terbanglah.'

Arti harfiah kaze adalah angin, yakni udara yang bergerak. Dalam permainan shabondama, angin dianggap sebagai sesuatu yang dapat mengganggu permainan jika terlalu kencang. Angin membuat pergerakan shabondama lebih cepat, dan karena rapuh pergerakan yang cepat dapat menghancurkan shabondama. Karena angin pula shabondama dapat saling bertabrakan atau menabrak benda lain sehingga pecah. Tanpa angin, karena massa jenis shabondama ringan, dapat terbang melayang lebih lama, lebih jauh, dan lebih tinggi. Dalam bait ini nampak pengarang membuat permohonan agar kaze tidak bertiup. Kaze adalah metafora dari sesuatu dalam jumlah tak terhitung, tidak terlihat namun dapat dirasakan keberadaannya, serta luas pengaruhnya. Ada kemungkinan ini adalah analogi dari semacam wabah penyakit. Dengan demikian pesan dari bait terakhir ini adalah sebuah permohonan agar wabah penyakit yang menimbulkan banyak kematian dapat berakhir supaya anak-anak dapat hidup lama. Bait terakhir ini menurut penulis menjadi inti dari pesan atau makna lirik lagu Shabondama, yaitu sebuah doa atau permohonan agar dijauhkan dari penyakit atau penderitaan yang melanda anak-anak di Jepang pada saat itu.

Hasil pembacaan hermeneutik lirik lagu Shabondama berdasarkan studi interteks juga dapat memunculkan pemaknaan yang lain apabila melihat kondisi sosial, budaya, serta politik Jepang pada saat lirik diciptakan. Kita tahu bahwa kondisi masyarakat Jepang pada saat itu adalah masa transisi, yaitu masa pergerakan menuju negara demokrasi. Jalan yang ditempuh Jepang adalah westernisasi, yaitu dengan berkiblat kepada negara-negara Barat, seperti Jerman, Inggris, Prancis, dan Amerika. Pada saat itu budaya Barat masuk ke Jepang dengan derasnya meliputi 
banyak segi kehidupan, terutama teknologi, industri, dan politik. Kebijakan yang dimulai pada masa Meiji tersebut memang dengan segera menampakkan hasil. Jepang tumbuh menjadi negara maju yang disegani oleh negara-negara lain. Namun, tidak semua bidang berdampak positif. Kemajuan ekonomi yang dicirikan dengan munculnya zaibatsu (konglomerat) menimbulkan kesenjangan sosial, terutama dengan mayoritas para petani. Kemajuan di bidang teknologi, terutama militer telah menimbulkan paksaan-paksaan kepada masyarakat Jepang untuk mendukung program pemerintah yang di atas namakan Kaisar yang suci dan agung. Juga, westernisasi yang tentu saja mau tidak mau mengikis ideologi bangsa.

Kesenjangan yang terjadi di dalam masyarakat Jepang, terutama tentu saja melahirkan pertentangan, terutama pertentangan antara golongan kapitalis atau pengusaha dan golongan buruh atau petani. Namun, karena otoritas negara yang begitu kuat dan tidak segan-segan menghukum orang yang dianggap menentang kebijakan negara, perlawanan mereka muncul dalam bentuk karya sastra. Karya sastra yang muncul dari kalangan bawah ini disebut sebagai sastra proletar. Tokoh yang muncul di kalangan ini di antaranya adalah Takiji Kobayashi, Sukeo Miyajima, dan Karoku Miyachi.

Pengekangan kebebasan dan westernisasi inilah yang banyak dikritik oleh warga yang menentangnya. Salah satu di antaranya adalah lagu shabondama ini. Shabondama di dalam lagu ini dapat dimaknai sebagai jiwa, jiwa bangsa Jepang, jiwa para petani dan buruh yang tertindas. Shabondama menjadi metafora dari jiwa, jiwa yang murni, yang rapuh karena tertindas tidak dapat berbuat apa-apa. Jiwa yang seharusnya dapat terbang bebas ke mana pun terhalangi oleh atap. Atap adalah bagian dari sebuah bangunan, sebuah bangunan negara Jepang. Jadi atap adalah metonimi dari bangunan yang menjadi metafora dari pemerintah Jepang yang menghalangi kebebasan bergerak jiwa rakyat Jepang. Jiwa orang Jepang juga telah dirusak oleh angin, yaitu metafora dari paham Barat yang telah menyebar di Jepang.

\subsection{Intertekstualitas, Matriks, Model, dan Varian}

Untuk menemukan matriks yang menjadi pusat makna atau pesan utama dari lagu shabondama secara lebih akurat akan lebih baik jika melihat karya-karya lain yang muncul sebelumnya dari pengarang. Dalam pembacaan hermeneutik sebenarnya selain mengungkap 
ketidaklangsungan ekspresi juga sudah membahas studi interteks, tepatnya yang disebut hipogram aktual, yakni dengan melihat teks latar belakang kehidupan pengarang dan latar sosial, budaya, dan politik saat lagu diciptakan. Untuk melengkapinya di bagian ini diberikan studi interteks berdasarkan karya-karya sebelumnya.

Beberapa karya yang dikarang Noguchi sebelum mengarang Shabondama adalah Nanatsu no ko 'Tujuh Anak Gagak', Aoi me no ningyo 'Boneka bermata biru', Akai kutsu 'Sepatu Merah'. Karya yang pertama menceritakan kesedihan ibu gagak yang meninggalkan tujuh anaknya di rimba pegunungan, yang kedua tentang kecemasan boneka dari Amerika yang baru didatangkan ke Jepang, dan yang ketiga tentang anak perempuan Jepang bersepatu merah yang dibawa pergi oleh orang Amerika (https://www.japantimes.co.jp/ news/2007/06/19/reference/small-statuein-azabu-juban/\#.Xzv rugvPIU). Dari ketiga karya tersebut ada benang merah yang mengaitkannya, yaitu ketidakberdayaan, ibu gagak hanya dapat menangis karena terpisah dengan anaknya, boneka Amerika tidak berdaya apa-apa didatangkan ke dunia baru di Jepang, dan yang ketiga pengarang tidak dapat berbuat apa-apa untuk mencegah anak perempuan Jepang yang dibawa oleh orang asing yang tentunya akan mengubahnya menjadi orang asing juga. Selain itu, juga terdapat persamaan di antaranya ketiganya yaitu keterpisahan jarak, yang pertama antara tempat ibu gagak dan pegunungan, dan dua yang terakhir Jepang dan Amerika. Implikasinya adalah ada dua tempat berbeda berarti ada dua budaya yang berbeda pula, dan tokoh yang ada dalam cerita harus memasuki dunia baru yang menyebabkan keterasingan. Ada suatu kekuatan yang ia tidak sanggup melawannya sehingga terpaksa masuk ke dalam dunia baru yang asing.

Shabondama pun kelihatannya dikarang dengan matriks yang sama, yaitu nosi tentang ketidakberdayaan. Baik dimaknai dengan kematian anak-anak maupun penjajahan atas jiwa yang bebas, nampak ketidakberdayaan pengarang dalam mengatasi fenomena yang terjadi. Kelemahan ini dinampakkan dalam model, yaitu permohonan agar penderitaan segera berakhir. Pengarang hanya dapat berdoa dan berharap "Oh angin, janganlah bertiup. Biarkan shabondama terbang..." Adapun baris-baris yang terdapat dalam bait pertama dan kedua menjadi varian, yang merupakan penjabaran tentang keadaan-keadaan yang membuat ketiadaberdayaan. 


\section{Simpulan}

Puisi ataupun lirik lagu merupakan karya seni atau lebih khususnya lagi adalah karya sastra yang menggunakan media bahasa. Namun berbeda dengan penggunaan bahasa secara umum, dalam puisi selain menggunakan bahasa yang tidak langsung, juga menggunakan bahasa yang dapat menyentuh perasaan. Pemaknaan puisi harus memetakan kaitan-kaitan antara diksi yang digunakan dengan makna yang tersirat. Ancangan semiotika adalah salah satu cara yang efektif untuk memaknai puisi, karena bahasa yang digunakan merupakan tanda yang mewakili makna yang lain.

Dalam pemaknaan puisi atau lirik lagu Shabondama, penulis telah menjabarkan bagaimana memaknai lirik Shabondama berdasarkan teori semiotika puisi Riffaterre. Shabondama, yang merupakan lagu anak-anak, ternyata memiliki makna yang justru jauh dari dunia anak-anak, yaitu ketidakberdayaan. Inilah hipogram atau matriks yang menjadi pusat makna dengan varian-variannya berupa penggambaran shabondama yang pecah karena tiupan angin atau terkena atap. Permohonan dan harapan menjadi model yang merepresentasikan makna ketidakberdayaan.

Pemaknaan karya sastra memang menjadi wilayahnya pembaca, karena pembaca hanya berhubungan dengan teks yang dibaca dan tidak berhubungan dengan pengarangnya. Terjadi dialekta antara teks dan pembaca. Oleh karena itu, sah saja jika dalam memaknai sebuah karya sastra berbeda dengan maksud sebenarnya dari pengarang. Apa yang dihasilkan dalam tulisan ini, dapat menjadi alternatif pemaknaan karya sastra berdasarkan teori Riffaterre.

\section{Referensi}

Aminah, S. (2015). Dinamika Kesusastraan Modern: Ambiguitas antara Tradisi dan Modernitas. In researchgate.net.

Beasley, W. G. (2003). Pengalaman Jepang: Sejarah Singkat Jepang. Yayasan Obor Indonesia. Riffaterre, M. (1978). Semiotics of Poetry. Indiana University Press.

Riffaterre, M. (1983). Text Production. Columbia University Press.

Saifudin, A. (2012). Metafora dalam Lirik Lagu Kokoro no Tomo Karya Itsuwa Mayumi. Lite: Jurnal Bahasa, Sastra, Dan Budaya, 8(2), 89-105. 
Saifudin, A. (2018). Konseptualisasi Citra Hara 'Perut' dalam Idiom Bahasa Jepang. Japanese Research on Linguistics, Literature, and Culture, 1(1), 65-78. https://doi.org/10.33633/jr.v1i1.2130

Teeuw, A. (1984). Sastra dan Ilmu Sastra. Pengantar Teori Sastra. Jakarta: PT Dunia Pustaka Jaya. Yorice, N., \& Noviana, F. (2016). Keterkaitan Makna dalam Tiga Lirik Lagu Anak Jepang Era 1920an Karya Noguchi Ujo Ditinjau Melalui Pendekatan Ekspresif.

http://eternal-life.la.coocan.jp/preachings2008/08.09/09.17.htm

https://www.japantimes.co.jp/news/2007/06/19/reference/small-statue-in-azabujuban/\#.Xzv rugvPIU

https://peoplepill.com/people/ujo-noguchi/ 